Arab World English Journal (AWEJ) Volume 12. Number1 March 2021

Pp.215 -228

DOI: https://dx.doi.org/10.24093/awej/vol12no1.15

\title{
EFL Learners' and Teachers' Perception toward the Use of Online Videos in EFL Classes
}

\author{
Doniazad Sultan Alshraideh \\ English Language Centre, Taibah University \\ Madinah, Saudi Arabia \\ Email: doniazadsh@yahoo.com
}

Received : 12/26/2020

Accepted: 2/3/2021

Published:3/24/2021

\begin{abstract}
:
This study aims at analyzing the English as a foreign language (EFL) learners' and teachers' perception toward the use of online videos in EFL classes. The current study used a mixed method to answer the question of the study which is: What is the perception of EFL learners and teachers toward the use of online videos in EFL classes? It includes both quantitative and qualitative techniques, namely a questionnaire and an interview. To get the required data and to answer the question of the study, the researcher collected information by distributing a relevant questionnaire among 120 EFL Saudi female students who are studying English in their preparatory year "Unified Scientific Track" at Taibah University. Their ages range between 18 to 21 years old. The questionnaire of the study consists of 10 items. For the first nine items, Likert Scale is used to let the respondents range the statements on a five- point scale. The tenth item asks the respondents to rate the usefulness of the online video regarding language skills and other aspects. The researcher also conducted an interview with six EFL teachers who teach English language skills in the English Language Centre (ELC) at Taibah University. The responses of the participants showed that the use of online videos is an effective technique and has a positive influence in EFL classes.
\end{abstract}

Key words: EFL learners, language skills, online video, perception, technology

Cite as: Alshraideh, D. S. (2021). EFL Learners' and Teachers' Perception toward the Use of Online Videos in EFL Classes. Arab World English Journal, 12 (1) 215 -228.

DOI: https://dx.doi.org/10.24093/awej/vol12no1.15 


\section{1-Introduction}

Using technology in education is becoming a must all over the world these days as it facilitates, strengthens, and supports the education system in general. According to Hatlevik et al., (2013), during the last ten years, there has been much focus on the place of technology in education. What technology has added and is still adding in education is revolutionary, and the impetus toward more changes is irreversible (Hardin and Ziebarth, 2000). Peña-López(2015) states that effective and operative use of computers in schools leads to qualifying better teachers and improve learning material. Saudi Arabia is one of the concerned and interested countries that play an important role in using technology in the teaching/learning process in general. For example, Altowjry (2004) conducted a research regarding the development of the educational system in Saudi Arabia by using telecommunications technologies and by incorporating the distance learning method. The findings show that there is a positive relationship between applying the new method of distance learning and decreasing the number of students who drop out of the educational process for many reasons. Also, Al-Fahad(2009) tried to determine how mobile learning technology can be applied to improve students' retention at the Bachelor of Art and Medicine programs at King Saud University in Saudi Arabia. The results of the study indicate that using mobiles in learning could be a beneficial method that improves the retention of students as it enhances their teaching/learning process.

On the other hand, the English language is one of the subjects given important attention in Saudi Arabia Aljohani (2016)states that "The Ministry of Education shows its support by offering English classes in Saudi schools and assigning supervisors to evaluate and adjust the teaching methods and the teacher's techniques"p.8. Many EFL methods, techniques, and strategies are used to teach English effectively. One of these strategies is using technology. The variety of applications and features that technology devises contain is providing the EFL learners with multiple ways to learn English. Pourhosein Gilakjani \& Sabour (2017) points out that technology has changed language teaching methods, and the application of technology helps learners learn according to their interests. Online video applications become a basic classroom instrument that plays a real and important role in enhancing learning English. Asensio and Young (2002) state that using a moving image is a good way that might be implemented for educational purposes in order to clarify information. Also, Jensen et al. (2011) state that including videos to the language learning process provides learners with many opportunities to learn the language within the classroom by a dynamic and interactive atmosphere which might help them promote their confidence and individual dependence.

\section{2-Literature Review}

\section{2-1 Using Technology in EFL Classes}

Using technology in EFL classes can be a useful method and a valuable technique. Many EFL teachers have taken information technology (IT) courses in order to be educated enough to use technology in their EFL classes. According to Bull and Ma (2001), the use of technology provides language learners with a lot of resources. Becker (2000) states that computers are important educational instruments in language classes as teachers could have convenient access, prepare their lessons properly with a kind of flexibility with the curriculum they use.

Moreover, Boukadi (2014) conducted a study to investigate teachers' experiences and perceptions regarding the use of technology in foreign language teaching. According to the 
study, three teachers were interviewed. One of the study's finding was that the teachers agreed that the students still need the training to be able to use technology properly. Furthermore, they were all in favor of the use of technology as it makes their teaching more effective and helps meet the needs of the students. Besides, they agreed that teachers need to be proficient in using technological devices to apply them in their teaching classes. Cutter (2015) also claims that technology helps increase learners' motivation. When students use computers and modern devices, they become more motivated than when using their own textbooks.

On the other hand, some teachers have a negative attitude toward the use of technology in general and in their classes in particular. Pourhosein Gilakjani \& Sabouri (2017) states that the attitudes of the teachers toward the use of technology affect the way they apply it in their classes. Mohamed (2014) claims that students are more capable of using technology than teachers and that might be an essential factor for some teachers not to use computers and technology in classrooms. It is better for them to attend professional training courses to be skillful in using technology in teaching.

\section{2-2 Why online videos?}

Online videos are used for many educational purposes. Teachers, as well as their students, can get a lot of pedagogical strategies and information that strengthen their understanding and foster their teaching-learning process. Mayer (2005) says that "videos are defined as "multimodal texts, which means that the material is presented in both verbal and pictorial form."p.2. Lonie, Louise, and Andrew(2009) state: "virtual classrooms, web conferencing, and streaming, self-paced content provide both students and teachers with dynamic and visual resources that have now been accepted as a framework for successful learning”.p.7. Burta (2007) claims that online videos are valuable, and they motivate students to be more active while learning. Besides, Adam and Mowers(2007) argue that online video sites like YouTube (www.youtube.com) have been recently used as a new tool in classrooms. Also, according to Friedman and Friedman(2013), more than $30 \%$ of college students have attended one or more online courses. Zhang, Zhou, Briggs, and Nunamaker (2006) conducted a study about the interactive video in which video segments are chosen directly for study. Then, the video is divided into segments and then the segments are played via action selected interface. The study reveals that using videos that way improves learning. According to the previous studies, it seems that the use of videos in the teaching-learning process has been investigated in many research papers and studies, and it has many benefits in this field.

\section{2-3 Online videos in EFL classes}

According to recent studies, the use of online videos in EFL classes has become one of the effective and efficient methods in teaching and learning English. Harmer (2006) points to the use of videos as a useful tool. He claims that it enhances students' learning experiences; it assists them in using a language properly and becoming more creative. It also deepens their cultural understanding and increases their motivation in learning. According to the study which was conducted by Mohammed (2013), he uses the subtitled videos in order to teach grammar. The findings reveal that students' grammatical accuracy was developed. He explains the results by referring to the role of using pictures and texts to attract the students' attention rather than using the text only. Progosh (1996); Canning-Wilson (2000); Rammal (2006), point out the usefulness of Video-based materials in teaching EFL learners. 
To sum up, no one can deny that online videos are increasingly used in teaching EFL learners, and it has a positive effect that deserves to be studied in different language areas. This study aims to find out the EFL learners' and teachers' perceptions toward the use of online videos in EFL classes.

\section{3- Research Questions}

This study aims to answer the following questions:

1- What is the perception of EFL learners toward the use of online videos in EFL classes?

2- What is the perception of EFL teachers toward the use of online videos in EFL classes?

\section{4- The context of the study}

In order to answer the first questions, the researcher has prepared a questionnaire and distributed it among 120 EFL Saudi female students who study English in their preparatory year "Unified Scientific Track" at Taibah University. Their ages range between 18 to 21 years old. For the second question, the researcher has interviewed six EFL teachers who teach English language skills for two terms (14 teaching weeks with 224 hours per term).

\section{5- Significance of the study}

Using online video classes have become a vital tool for most, if not all, EFL teachers. It provides EFL teachers with authentic resources that facilitate teaching English and making it more interesting and dynamic which attracts and encourages EFL students to learn English and provide them with the opportunity to listen as many times as required until mastering their lesson. It also saves their time and their efforts in conveying the message 'topic of the lesson' if they invest it in a professional way. Moreover, the students may come back to the video in their free time. According to Berk (2009), teachers have many choices of video types that are used in the classrooms depending on the objectives of learning, students' characteristics, and their needs and interests. On the other hand, EFL students can benefit more when they follow effective methods while using online videos in learning English. Alimemaj(2010) states that using YouTube can provide students and teachers as well with many authentic examples of everyday English that are used by native speakers of English in their daily life.

The current study will provide the EFL teachers and educators with important information about the use of online videos in EFL Classes, and how to make it beneficial while presenting them in English classes and the best methods that might be used to apply it professionally.

\section{6-Methodology}

\section{6-1 Participants}

The study population consists of 120 EFL female Saudi students and six EFL female teachers. The students study English as a foreign language in the Unified Scientific Track at Taibah University. Their ages range from 18 to 21. Their level of proficiency in English is varied. According to the teachers, they teach English as a foreign language. Two of them have their $\mathrm{PhD}$ degree in TEFL. Other teachers have their M.A. degree in different fields of English. Their experience of teaching is varied. Three of them have been teaching for more than 15 years. There are two teachers who have been teaching English for more than six years. One is a new teacher. Her experience was one year. 


\section{6-2 Research Design}

At the end of the year, the researcher distributed a questionnaire to the students. The students completed the questionnaire to reflect their perceptions toward the use of online videos in EFL classes. For the EFL teachers, they were all interviewed by the researcher. They answered the questions in a friendly relaxed atmosphere. There were six questions. Each teacher spent between five to seven minutes answering the questions.

\section{6-3 Data Collection}

This study uses a mixed-method to answer the questions of the study. It includes two instruments, namely, a questionnaire and an interview. To get the needed data and to answer the questions of the study, the researcher collected the information by distributing a relevant questionnaire among 120 students and conducting an interview with six EFL teachers.

\section{6-4 Questionnaire}

A questionnaire is an important instrument that can be used to collect data regarding the topic of any study. It should be planned carefully in order to elicit the needed data which are related, vital and sufficient from the respondents to accomplish the goal it is designed for. Check and Schutt (2012) state "A common survey method is the questionnaire, which is "a survey instrument containing the questions in a self-administered survey."p.161.

The questionnaire used in the current study is directed to the EFL learners to gather information about their perceptions toward the use of online videos in EFL classes. The questionnaire of the study consists of 10 items. For the first nine items, Likert Scales is used to let the respondents range the statements on a five-point scale. According to Dörnyei (2007), "A Likert scale item requires the respondent to indicate to which extent they "agree" or "disagree" with a statement." p.105. The tenth item asks the respondents to rate the usefulness of the online video regarding language skills and other aspects.

\section{6-5 Interview}

The other instrument that the researcher used to collect data is the interview. The use of an interview could be a successful way to gather information if the questions of the interview are professionally selected and intelligently asked to the interviewee. According to Dufva (2011), interviews could be a meaningful method to let the examinees express their opinions and experiences. Also, the environment in which the interview takes place should be comfortable, suitable, and motivating one. According to this study, there are six related questions. The environment is friendly and encouraging. The questions are asked to six EFL teachers to reveal their perceptions toward the use of online videos in EFL classes.

\section{6-7 Data Analysis and Findings}

After collecting the responses of the participants of the questionnaire, the researcher utilized the quantitative data of the questionnaire and presented them in Appendix A. The questionnaire is also analyzed qualitatively.

\section{7- Discussion:}

The students' responses to the questionnaire are shown on Table 1. 
Arab World English Journal (AWEJ) Volume 12. Number 1. March 2021

EFL Learners' and Teachers' Perception toward the Use of Online

Alshraideh

Table 1 Students' Perceptions of Using Online videos in EFL Classes

\begin{tabular}{|c|c|c|c|c|c|}
\hline Item & SA & A & $\mathrm{N}$ & $\mathrm{D}$ & SD \\
\hline 1-Mean & 72.5 & 10.83 & 5.83 & 7.5 & 3.3 \\
\hline 2-Mean & 95 & 4.16 & 0,83 & 0 & 0 \\
\hline 3-Mean & 70 & 9.17 & 7.5 & 5 & 8.33 \\
\hline 4-Mean & 85.83 & 12.5 & 0.83 & 0.83 & 0 \\
\hline 5-Mean & 65.8 & 7.5 & 9.2 & 5.8 & 11.7 \\
\hline 6-Mean & 85 & 3.3 & 5.8 & 4.2 & 1.7 \\
\hline 7-Mean & 69.2 & 20.8 & 7.5 & 0 & 2.5 \\
\hline 8-Mean & 77.5 & 15 & 4.2 & 3.3 & 0 \\
\hline 9-Mean & 63.3 & 19.2 & 8.3 & 4.2 & 5 \\
\hline 10 Rating & - & - & - & - & - \\
\hline 1.Listening $\backslash$ Mean & 80 & 10 & 5.8 & 2.5 & 1.7 \\
\hline 2.Speaking\Mean & 57.5 & 29.2 & 7.5 & 1.6 & 4.2 \\
\hline 3.Reading $\backslash$ Mean & 39.2 & 9.2 & 30.8 & 7.5 & 13.3 \\
\hline 4.Writing\Mean & 15.83 & 3.33 & 20.83 & 17.5 & 42.5 \\
\hline 5.ocabularylMean & 11.7 & 57.5 & 17.5 & 5.8 & 7.5 \\
\hline 6.GrammarlMean & 5.83 & 23.33 & 4.16 & 25.83 & 40.83 \\
\hline 7.pronunciation $\backslash$ Mean & 69.2 & 18.3 & 5.8 & 2.5 & 4.16 \\
\hline 8.Spelling\Mean & 5.8 & 15 & 7.5 & 28.3 & 43.3 \\
\hline
\end{tabular}

Table 1 reveals that upwards of $87 \%$ of the respondents strongly agree and agree with the use of online videos in EFL classes. Most of them perceive that it is useful, while $7 \%$ do not agree with that. For the first statement which asks the students if using online videos makes their classes more interesting, $83 \%$ agree and strongly agree with this statement, while $10 \%$ disagree. The use of online videos in EFL classes may create a good environment for the students to communicate and interact with each other to discuss the information they get from the videos they watch and enhance their understanding of the topic which let them feel that the class is more interesting. 99.16\% agree and strongly agree with the statement that the online videos they watch in their classes are relevant to the course content which indicates that teachers are really care about the content of the videos they show to their students in their EFL classes. Only84\% disagree with that. According to the third statement that using the online videos enhances their participation in the classroom, $95 \%$ agree and strongly agree with this statement. This means that it motivates them to participate more when they watch the videos. Callow and Zammit (2012) point out that students' participation and involvement can be improved more by using YouTube 
in the classroom and learning strategies. Regarding the fourth statement that watching the online videos develops their overall comprehension of the lesson, 98\% agree and strongly agree with this statement. As for the respondents who disagree, there is only $0,83 \%$. The fifth statement asks the students whether online videos are beneficial sources for Learning English language, $88 \%$ of the respondents agree and strongly agree with the statement, while $21 \%$ do not. A percentage of $21 \%$ of the students, they may prefer traditional methods of teaching and learning by using their textbooks. For the sixth statement 'using online videos motivates me to learn the English language', more than $88 \%$ agree and strongly agree with the statement. They might feel that watching videos provide them with a dynamic environment and more active classes that encourage them to learn English. The percentage of the responses of those who disagree with this statement is just 5.9\%. According to the seventh item which asks the students if watching online videos deepens their understanding of other cultures, the percentage of the students who agree and strongly agree is $90 \%$. This might be considered as a good indicator that the students use online videos to be educated about other cultures, especially with the ease of accessing the net and searching about any cultural topic they might be interested in while learning English. The respondents who disagree with the statement are only $2.5 \%$. The eighth statement about discovering new information via online videos', the responses for this statement are clearly high, $92.5 \%$ of the respondents agree and strongly agree with the statement, while $3.3 \%$ do not. The students may find it easier to use online videos in order to get more information about any topic they need. The ninth statement asks the students if they recommend the use of online videos in learning English, $82.5 \%$ of the respondents agree and strongly agree with this statement, while $9.2 \%$ do not. Students can use online videos in their daily life and they might depend on them as aiding tools to facilitate their studying and learning. They share the videos and tell each other about the videos that help them to increase their understanding of any topic they need to learn it better in English. The tenth statement of the questionnaire asks the students to rate the usefulness of the online video regarding language skills and other aspects. According to the listening skill, $90 \%$ of the students rate it useful, while $4.2 \%$ rate is not useful. When the students watch a video, they listen to the information at the same time, so they might develop their listening skills unless the video has no sound or they watch a video with a different language. For that reason, teachers should take that into their consideration while preparing the video they use in EFL classes. They should show their students a video using English language sounds to guide the subject if they want to use the online video as a learning tool to enhance the students' listening skill besides any other language skill. Harmer (2001) claims that one advantage of using videos in EFL classes is that it allows the EFL learners to listen to the language. The second skill is speaking, the respondents who consider it as a useful tool for speaking skill are $86.7 \%$, and this percentage indicates that most of the respondents find online videos as an efficient tool in improving speaking skill. For this skill, only 5.8\% of the respondents find it not useful. Busà (2010) states that listening to people when they are speaking about their real-life experiences and communicating with speakers in a usual way might be more effective than listening to actors while they are reading scripts elaborated by EFL (English for Foreign Language). Also, Lee (2007) states that via videos, students can become more fluent in oral skills as they pronounce the words they listen to while watching the video. The third skill is that of reading. For this skill, $48.4 \%$ find it useful, while $20.8 \%$ find it not useful. $30.8 \%$ is neutral. This percentage may refer to the fact that students pay more attention to what they hear and try to focus more on listening and speaking skills while watching videos. However, when students listen to the video and if there is subtitles, they might improve their reading. The fourth skill is the writing skill. The 
percentage of respondents who rate it as a useful skill is 19.16 , while $60 \%$ find it not useful. Compared to the previous skills, it is the lowest percentage. The students may find online videos not useful enough for writing. It might refer to their interest while watching the video. If the teachers want their students to get benefit from the online videos for writing, they should prepare and plan suitable videos with appropriate strategies to attract their students' attention to applying what they watch to learn writing. Moving to the fifth language aspect which is vocabulary, the percentage of the respondents who rate it as a useful tool to learning vocabulary is 69.2 , whereas $13.3 \%$ reflect on it as being not useful one. According to the findings, it is clear that many of the participants think that the use of online videos is an effective method to learn vocabulary. According to many studies, EFL learners use movies to learn English while watching movies. They try to get benefits from what they hear to improve their acquisition of vocabulary. For the next language aspect which is grammar, only $29.16 \%$ consider it as a useful device to learn grammar, but $66.66 \%$ reflect on it as not useful. It could refer to the students' concentration on and interest in other aspects of language. While watching videos, students usually focus on listening, vocabulary, speaking...etc. instead of paying attention to grammar. According to the pronunciation aspect, $87.5 \%$ of the respondents find online videos as a useful tool, whereas $6.66 \%$ consider it as not useful. when students watch and listen to hear the video, they may benefit and improve their pronunciation of the words of the target language. For that reason, teachers should focus on the content and prepare audio-visual videos that can help students improve their pronunciation. Richards and Renandya (2002) claim that encouraging students to speak the target language could be done by giving them an opportunity to use the language through extensive exposure to it via audio-visual stimuli. The last aspect is that of spelling. $20.8 \%$ of the respondents rate it as a useful tool, while $71.6 \%$ do not. The reason for such a percentage could be the fact that the videos they watch might not contain captions or subtitles. Also, the responses may indicate that most of the respondents do not care to the spelling of the words if the videos have captions or transcripts.

To sum up, the findings of the questionnaire reveal that most of the respondents find the online videos are useful in EFL classes and they could be a useful and effective method in learning English language. Harmer (2007) points that using videos to learn a language increases the learners' motivation. Also, Mekheimer (2011) concludes "Integrating video-based material with whole language teaching of the language skills of our students in a fashion that ameliorates viewing comprehension can produce an enhanced overall linguistic proficiency in EFL students at university levels." (p.27).

\section{8- Interview Results}

For the interview, the researcher collected the data from the interviewees. The responses were:

The first questions" Do you think using online videos is useful in EFL classes? How? The first teacher said:" Using online videos is very beneficial in teaching in general and in EFL classes in particular. It facilitates teaching and motivates our student to learn visually and audibly. The second teacher commented:" Utilizing online videos in my classes as EFL teacher is valuable for me and my students as well. It gives them an opportunity to learn the language with a relaxed atmosphere. For me it is a supplementary useful tool. However, teachers should be vigilant when preparing the video material they want to show to their students. The answer of the third teacher was:" I like to apply different methods and techniques in my class. It is a good way 
to get learners' attention. No doubt that social media has an effective way in education in general and online videos might be so beneficial, but I like using it whenever I need it. Sometimes it is very efficient, while other times I feel it is just a waste of time, so I do my best to employ it when it is a source of enrichment material. The fourth teacher replied: "It's a good tool to enhance learning in general. This generation uses online videos in their daily life, so why not to get benefit from that point while teaching them. It is absolutely an interesting and favorable way to teach EFL students". The fifth teacher said:" I think it is has two sides, I mean it could be a good way if the teacher is really cares about the learners because he should be very careful while using on line videos in the class. On the other hand, it could be a negative tool if the teacher uses it without planning". The sixth teacher's answer was" Ignoring online videos as a technique in teaching is like ignoring essential ingredients of a certain .meal. I am totally in favor of utilizing this strategy as we live in the age of technology. It makes teaching more effective, interesting and active.

The answers of the teachers clarified their opinion and attitude regarding the usefulness of the online videos in EFL classes. All of them consider it as an efficient technique, but it should be used carefully and in an organized and planned way.

For the second question 'What impact do you think online video have on students' engagement, motivation, and achievements? The answers were:

The first teacher commented:" I think it has appositive impact on students' engagement by stimulating them to talk about the topic of the video they watch. They share their ideas and try to use their background information when they learn that way. According to their motivation, as I mentioned it motivate them positively. Regarding their achievement, well! It may encourage them to improve their language and a result, their achievement could be better". The second teacher said:" Students are trying to share their ideas when they watch a video which is related to their interests and they like to talk about the scenes they watch with each other. Especially, our students are fond of social media. It is a good chance for my students to feel that they are watching a video and learning at the same time. Their social interaction after watching the video may motivate them intrinsic and extrinsic. I think that using videos might affect their achievement if they understand and the teacher was properly using the related material that they really need in learning the language. The third teacher replied that it could be a good tool that enthusiasts the learners improve their engagement with each other. They try to make comments while watching the video and keep sharing their ideas and concepts that might be related to the topic of the video. For motivation, yes. I think learners become a kind of motivated while having videos in their EFL class. Regarding their achievement, it depends on their understanding and many other factors like their language level and language proficiency. The fourth teacher said:" Yes, It is an amazing tool that I use and I think it is an engaging and motivating classroom device for teaching English language. As it enhances their learning in general, it also has its effectiveness in developing their achievement. The fifth teacher commented:"If I use it, I will be sure that it has a positive impact on their engagement. I will let them feel that it is a way to motivate them and attract them to participate. Choosing the content of the video will be carefully planned. For their achievement, it is a good way, but actually, it depends on them". The sixth teacher said:" It is absolutely magnificent and has a positive impact. It could be an effective tool that increases student's engagement while watching a related well planned video. It also stimulates the students' motivation. As a result, it may improve their achievement. 
For the third question of the interview "When do you think using online videos is appropriate while teaching the lesson, at the beginning, in the middle, or at the end of the lesson? the first teacher said:" Personally, I believe that teachers should prepare carefully the material they want to use in the class, and it should be related to the topic of the lesson. It could be presented at the beginning, in the middle, or at the end of the lesson. It depends on when it is going to be efficient". The second one states:" There is no specific time to use the video. I just use it when I feel my students need it and it may facilitate my teaching. I also use it when it adds something to them like new information or creative ideas...etc. I just do my best not to use it meaninglessly". According to the third teacher, her answer was" As I mentioned before. I use it whenever I find it beneficial. I don't like to let my students depend on social media to enhance their language. As teachers, we should manipulate our students into seeking success by their own techniques and their ways of learning". The fourth teacher responded by saying:" It is a must that teachers should deeply think before choosing the video. Her choice will affect the process of teaching and learning. The appropriate videos can direct the class achieve the goal the teacher has set. I prefer using it when it is the best for my students and if it adds something valuable or assist my teaching process". The fifth teacher said:" As I mentioned before, the teacher should prepare the material wisely. When hel she feels it is suitable to use it, he could do that. No specific time. It depends on the many factors and only the teacher can decide when and how to apply it". The sixth teachers' replied by saying:" In my view, it could be used whenever the teacher finds id beneficial. There is no definite time. It might be used to introduce a certain topic, to explain a term or an idea,...etc".

According to the teachers' responses, they do not have a specific time to present and use the online video. It could be presented whenever the teacher, the learners, and the lesson require that. It means that whenever you need it, just use it. I think it is necessary to know when to present the online video to the learners to be sure that your class is interesting, engaging, and valuable at the same time.

The fourth question which was' How does it impact your time?. Following are the answers of the teachers:

The first teacher answered by saying:" Actually, it really influences my time effectively. It saves my time during the class when I prepare it properly". The second one said:" It actually consumes my time while trying to choose consciously the video. But when I use it in the class, I really find it the saver of my time". The third teacher's answer was:" I do my best to apply online videos when there is time for them. Sometimes using them is a time consuming, whistle other times, it saves my time. Actually, I can't guarantee my students reactions". According to the fourth teacher, she said:" It saves my time when I plan how, when and why to apply it. Otherwise, it consumes time". The fifth teacher said:" Of course it saves time, and that is one of the benefits of using it in my class". The sixth teacher replied by saying:" Well..it takes time when I prepare the lesson, but it saves my time when applying it”.

The teachers' answers were varied. That may be related to the many factors like, learners' needs, learners' levels, teachers' style of teaching, etc. On the other hand, the teachers agree that online video saved their time in general. 
The fourth question was "How would you rate the usefulness of the online video from 1 to 5 regarding language skills and other aspects? (Listening, speaking, reading, writing, vocabulary, grammar, pronunciation, and spelling). The answers were:

The first teacher answer was:" Umm... It is really effective and useful in teaching the whole skills, but according to the rating, it is 1 for listening as it it's so useful. For speaking it is 2. For reading it's 4 . It is 4 also for writing. 2 for vocabulary. 4 for grammar. It is 1 for Pronunciation, and if there are captions, it is 3 for spelling". The second teachers said:" It depends on many factors. If it is used with sound and captions, it could be very beneficial for the whole skills. In general, I will give 1 to listening and speaking, 3 for reading and writing. I give 2 for vocabulary. 3 for grammar and 2 for pronunciation. for spelling, 3". The third teacher replied by saying:" It is not easy to rate its effectiveness. In my view, it is useful for listening as well as for speaking, so it is 1 for these both skills. For reading..it might not be that efficient, let's give it 3 . For writing, it is not more than 4 . For vocabulary, well, it is 2.3 for grammar. 1 for pronunciation, and 3 for spelling". The fourth teacher said:" For listening skill, I think it is effective, so I'll give it 1. If the teacher knows how to apply it effectively, it might be very efficient for speaking. Let's say 2. Reading and writing skills. I rate them as 4 . Of course when students watch the video carefully and attentively. It will be useful to learn vocabulary. I will give it 2 . Not that effective for grammar, so it is 4 or 5. Pronunciation, well, it is 2 , and for spelling it is 3 ". The fifth teacher reply was:" For me, using online videos is effective in general, but is more effective for skills than others. If I want to rate its effectiveness, I think listening skill is 1 as they listen to what they watch. And that would be great for the students to listen to the target language while watching the video. Speaking needs practicing, so if they practice the language after watching, it would be very beneficial, so I will give it 2 . Reading takes 2 also, if it is supported with captions. For writing, I give it 4, It is not that beneficial. For vocabulary, it is 2 if the teacher directs them to focus on the key words. I will give 4 for grammar. 1 for pronunciation as the students hear the target language naturally". The sixth teacher's answer was:" It doesn't have the same rating... I find it so helpful for listening, so I'll give it 1. Speaking skill is a productive skill, but it depends on listening, so I think it has the same rating. Umm it is good for reading if the students focus on the caption and get benefit from what they listen to and apply it in reading, but I think it deserves 4. It is the same with writing. According to vocabulary, I feel it deserves 3 , but if the students know how to manipulate with the language they hear and listen to, the rating might become 1 . Grammar, I will rate it as 5. I think 2 for pronunciation and 5 for spelling".

The replies and the answers of the teachers may support the use of the online videos in EFL classes. Their ratings were different and vary. I think it refers to the fact that each learner has his her own style of learning. Also, the learners' motivation, abilities, and language proficiency might be vital factors in their learning.

The last question was:" Would you like to add any comments/ suggestions about using online videos in EFL classes? Following were the answers and the comments:

The first teacher commented:" I encourage EFL teachers to apply this technique in their classes. It is interesting as well as valuable". The second teacher said:" I am one of the teachers who is in favor of using this technique in EFL classes. However, teachers should use it appropriately and efficiently". According to the third teacher, she said" It is a good tool that might enhance students' language. However, teachers should be vigilant when they use this 
technique, and I encourage them to use it properly and accurately". The fourth teacher commented:" Absolutely, I encourage teachers not to ignore this tool in teaching. It could be one of their keys that enhances teaching and learning process". The fifth teacher said:" It needs teachers' desire and awareness to apply online videos in EFL classes. I do encourage them, but they should be careful and aware of some points like the learner's culture, needs, levels..etc". The sixth teacher replied by saying:" Yes of course, I advise all teachers to use online videos in TEFL, but they should be very cautious and careful when they choose the video as it affects their students behavior and attitudes".

According to the interview responses, it is clear that EFL teachers encourage the use of online videos as a technique to teach English language, most teachers recommend it as an effective tool. However, they assure the necessity of preparing and planning carefully the content of the video. Besides, teachers should present a useful and relative material that attract their students and let them get benefit from it.

\section{9- Conclusion}

Online videos are interesting and attractive teaching techniques that might help and facilitate teachers' missions if used professionally and carefully. This generation of learners is the generation of technology and they might be more motivated while using such techniques in learning English language. They also provide them with a good opportunity to learn the language authentically as they can hear the language from the native speakers if the teacher wants to focus on that point. The learners can get benefit from them to improve and develop all language skills. Teachers also might reduce the time they speak in the class and make it more efficient for the students. They open many doors that make teaching and learning the language more live and dynamic if they employ them proficiently.

\section{About the Author:}

Dr. Doniazad Sultan AlShraideh is an Assistant Professor at Taibah University. She received her Ph.D. in English Language Curriculum and Instruction Specification/TEFL from Yarmouk University, Jordan. Her research interests include: English Teaching Methods and Language Learning, Foreign language teaching and learning, and Second language acquisition. https://orcid.org/0000-0002-8461-5955

\section{References}

Adam, a., \&Mowers, H. (2007). YouTube Comes to the Classroom. School Library Journal, 53 (1), 22.

Al-Fahad, F. N. (2009). Students' attitudes and perceptions towards the effectiveness of mobile learning in King Saud University, Saudi Arabia. Online Submission, 8(2).

Alimemaj, Z. (2010). Youtube, Language Learning And Teaching Techniques.2(3), 10-12.

Aljohani,N (2016). English as a Second Language in Saudi Arabia. International Journal of Scientific \& Engineering Research, 3, (8) March-2016 ISSN 2229-5518

AlTowjri (2004). The Use of Telecommunication Technology. Rochester Institute of Technology. Winter 2004/05.

Asensio, M., \& Young, C. (2002). A learning and teaching perspective. Click and Go Video. Video Streaming-a guide for educational development. The JISC Click and Go Video Project, 10-19. 
Becker, H. J. (2000). Findings from the teaching, learning, and computing survey. Education policy analysis archives, 8,51 .

Berk, R. A. (2009). Multimedia teaching with video clips: TV, movies, YouTube, and mtvU in the college classroom. International Journal of Technology in Teaching \& Learning, 5(1).

Boukadi, S. (2014). CHAPTER FIVE CRITICAL APPROACH TO INTEGRATING ICT. Using Technology in Foreign Language Teaching, 83.

Bull, S., \& Ma, Y. (2001). Raising learner awareness of language learning strategies in situations of limited resources. Interactive Learning Environments, 9(2), 171-200.

Burta, D. (2007). Training the YouTube Way. Intranets, 10 (3), 1-3.

Busà, M. G. (2010). Sounding natural: Improving oral presentation skills. Language value, 2, 5167

Callow, J., \& Zammit, K.(2012). 'Where lies your text?' (Twelfth night act I, scene V): Engaging high school students from low socioeconomic backgrounds in reading multimodal texts. English in Australia, 47(2), 69-77.

Check, J., \& Schutt, R. K. (2011). Research methods in education. Sage Publications.

Cutter, M. (2015). Using technology with English Language Learners in the classroom.

DonYei, Z. (2007). Research methods in applied linguistics. Oxford university press.

Dufva, H. (2011). Eikysyvätieltäeksy: kuinkatutkiakieltenoppimista ja opettamistahaastattelunavulla. I: Alanen, R. \&Dufva, H. \&Kalaja, P.(red.): Kieltätutkimassa: tutkielmanlaatijanopas.

Erstad, O., Kløvstad, V., Kristiansen, T., \&Søby, M. (2005). Digital skolehverdag-om helhetligutvikling av digital kompetanse i grunnopplæringen.

Friedman, L. W., \& Friedman, H. (2013). Using social media technologies to enhance online learning. Journal of Educators Online, 10(1),1-22.

Harmer, J. (2001). Teaching with video. In A. Pearson Education Limited. Practice of English language teaching (pp. 282). England: Editorial logman.

Harmer, J. (2007). The practice of English language teaching. 4th ed. Harlow, UK: Pearson Longman.

Hardin, J., \&Ziebarth, J. (2000). Digital technology and its impact on education. The Future of networking technologies for learning.

Hatlevik, O. E., Egeberg, G., Gumundsd'ottir, G. B., Loftsgarden, M., and Loi, M. (2013).Monitor Skole 2013 - Om Digital KompetanseogErfaringer med Bruk av IKT i Skolen(NorwegianCentre for ICT in Education).

Jensen, M., Mattheis, A., \& Johnson, B. (2011). Using student learning and development outcomes to evaluate a first-year undergraduate group video project.CBE Life Sciences Education, 11(1), 68-80.

Lee, L. (2007). Fostering second language oral communication through constructivist interaction in desktop video conferencing. Language Annals, 40(4), 635-649.

Lonie,A.L.,\&Andrews,T.(2009). Creatinhg a Rich Learning Environment for Remote PostGraduate Leaners. Education inRuralAustralia,19(1),3-13.

Mayer, R., \& Mayer, R. E. (Eds.). (2005). The Cambridge handbook of multimedia learning. Cambridge university press.

Mekheimer, M. A. A. G. (2011). The impact of using videos on whole language learning in EFL context. Arab World English Journal, 2(2), 5-39. 
Mohamed, M. (2014). Using technology in EFL/ESL classroom. International Journal ofHumanities and cultural studies, Vol. 1 (2).

Mohammed, R. F. (2013). The effectiveness of using subtitled video to teach grammar.

Peña-López, I. (2015). Students, computers and learning. making the connection.Pourhosein, A., Banou, N.

Richards, J.C. \&Renandya, W.A. (2002).Methodology in Language Teaching: an Anthology of Current Practice. Cambridge: CambridgeUniversity Press.

Zabihniaemran, A. (2015). What are the barriers in the use of computer technology in EFL instruction?. Review of European Studies, Vol. 7 (11):213-221.

Zhang, D., Zhou, L., Briggs, R. O., \&Nunamaker Jr, J. F. (2006). Instructional video in e-learning: Assessing the impact of interactive video on learning effectiveness. Information \& management, 43(1), 15-27.

\section{Appendix}

EFL Students' Questionnaire on Using Online Videos in EFL Classes

Read each statement carefully then circle the number that matches your point of view. There are five possible choices as follow:

\section{Strongly agree Agree Neutral Disagree Strongly Disagree}

1. Using online videos makes my class more interesting.

2. The online videos I watch in my class are relevant to course content

3. Using online videos enhances my participation in the classroom.

4. Watching the online videos develops my overall comprehension of the lesson

5. Online videos are beneficial sources for Learning English language.

6. Using online videos motivates me to learn English language.

7. Watching online videos deepens my understanding of other cultures.

8. I like discovering new information via online videos.

9. I recommend the use of online videos in learning English

10. How would you rate the usefulness of the online video regarding language skills and other aspects?

5: not at all useful

\begin{tabular}{|l|l|l|}
\hline 5 & & \\
\hline Listening & & \\
\hline Speaking & \\
\hline Reading \\
\hline Writing \\
\hline Vocabulary \\
\hline Grammar \\
\hline Pronunciation \\
\hline Spelling \\
\hline
\end{tabular}

